\title{
Universal Design for Learning in postsecondary STEM education for students with disabilities: a systematic literature review
}

\author{
Jillian Schreffler ${ }^{1 *}$ D, Eleazar Vasquez $1 I^{1}$, Jacquelyn Chini ${ }^{2}$ and Westley James ${ }^{2}$
}

\begin{abstract}
Universal Design for Learning is not widely used in postsecondary STEM education. The purpose of this literature review is to synthesize the empirical literature using Universal Design for Learning in postsecondary STEM education for all learners. The criteria for this review are (a) empirical literature in (b) peer reviewed journals (c) published after 2006. Keywords used were STEM, UDL/UDI/Universal Design, and postsecondary/university/college/higher education. This review identified four studies and three literature reviews that met the search criteria; the analysis of the identified literature provides a model for how Universal Design for Learning can impact postsecondary STEM instruction, including an increase in inclusive teaching methods and self-advocacy from students with disabilities, and leads to recommendations for additional research.
\end{abstract}

Keywords: STEM, UDL, UDI, Universal Design, Postsecondary

\section{Introduction}

Nationally, fewer than $40 \%$ of undergraduates who intend to major in a STEM (science, technology, engineering, math) field complete a STEM degree (Olson and Riordan, 2012). Economic projections point to the need for an increase in the number of STEM degrees produced nationally (Olson and Riordan 2012). Many students with disabilities (SWD) are capable of completing STEM degrees and achieving STEM careers. However, many qualified students drop out before completing their college degrees, and individuals with disabilities represent an undertapped population in STEM (Stamp et al., 2014). Diverse learners are capable of becoming talented professionals in STEM, but they need opportunities to develop (Roberts 2010).

SWD have increased opportunities to attend postsecondary institutions (Newman et al., 2011). At 2-year and community colleges, SWD are significantly more likely to enroll in STEM majors compared to students

\footnotetext{
* Correspondence: jschreffler@knights.ucf.edu

${ }^{1}$ Department of Child, Family, and Community Science, University of Central Florida, Orlando, FL 32816, USA

Full list of author information is available at the end of the article
}

without disabilities (SWoD) (Lee, 2011) demonstrating an interest in STEM careers that does not currently result in equal representation. Surprisingly, in light of the reverse trend in the population of SWoD, low-income SWD are more likely to select STEM majors, possibly to increase their chances of securing employment, as individuals with disabilities are employed at a much lower rate $(18.28 \%)$ compared to individuals without disabilities (63.82\%) (Lee, 2014). However, Newman et al. (2011) reported based on the National Longitudinal Transition Study-2 (NLTS2) that less than 66\% of students with disabilities enrolled in any 4-year program actually complete the program within 6 years (SRI International, 2002). Completion rates between disabilities also fluctuated. Approximately, only 38.8\% of students with Autism completed their postsecondary education (Newman et al., 2011).

Large universities (i.e., $>20 \mathrm{k}$ students) often present all undergraduates in STEM fields with an array of institutional barriers that can be difficult to overcome. These obstacles can be compounded for students with disabilities (SWD) who may struggle with large class sizes, fast pace of instruction, lack of scaffolding in the 
curriculum, precision of the content, and the pedagogical approach from STEM faculty (Street et al., 2012). Traditional institutional reform efforts focus on system-level changes in instructor behaviors and supports. However, current institutional reform efforts have not had an immediate wide-scale impact on the attrition rate of STEM majors (Basham \& Marino, 2013). Universal Design is a promising strategy to support SWD, which emphasizes multiple ways of presenting curriculum to engage all learners (Basham \& Marino, 2013).

A review of literature in 2011 on Universal Design in postsecondary education suggested UDL in postsecondary education is lacking a significant research base (Roberts et al., 2011). This systematic review of empirical literature will investigate research involving Universal Design in higher education and how UDL is implemented in postsecondary education for STEM majors to help retention and persistence of students with disabilities.

\section{Universal Design's roots in architecture}

The term "Universal Design" (UD) was coined in 1988 by architect Ron Mace and his colleagues at North Carolina State University (Fig. 1). Mace defined "Universal Design" as "the design of products and environments to be usable by all people, to the greatest extent possible, without the need for adaptation or specialized design" (ACCESS Project, 2011, p. 1; U.S. Department of Housing and Urban Development, 1988). As architects, Mace and his colleagues were interested in designing buildings and roadways accessible to the entire public, including those with disabilities (College of Design, N. S. U, 2008). A familiar example of UD is the sidewalk "curb cut," which allows individuals with mobility disabilities to more easily transition from a sidewalk in to the roadway. While designed to meet the needs of individuals with disabilities, these curb cuts also improve the experience of individuals pushing strollers, bicyclers, and many

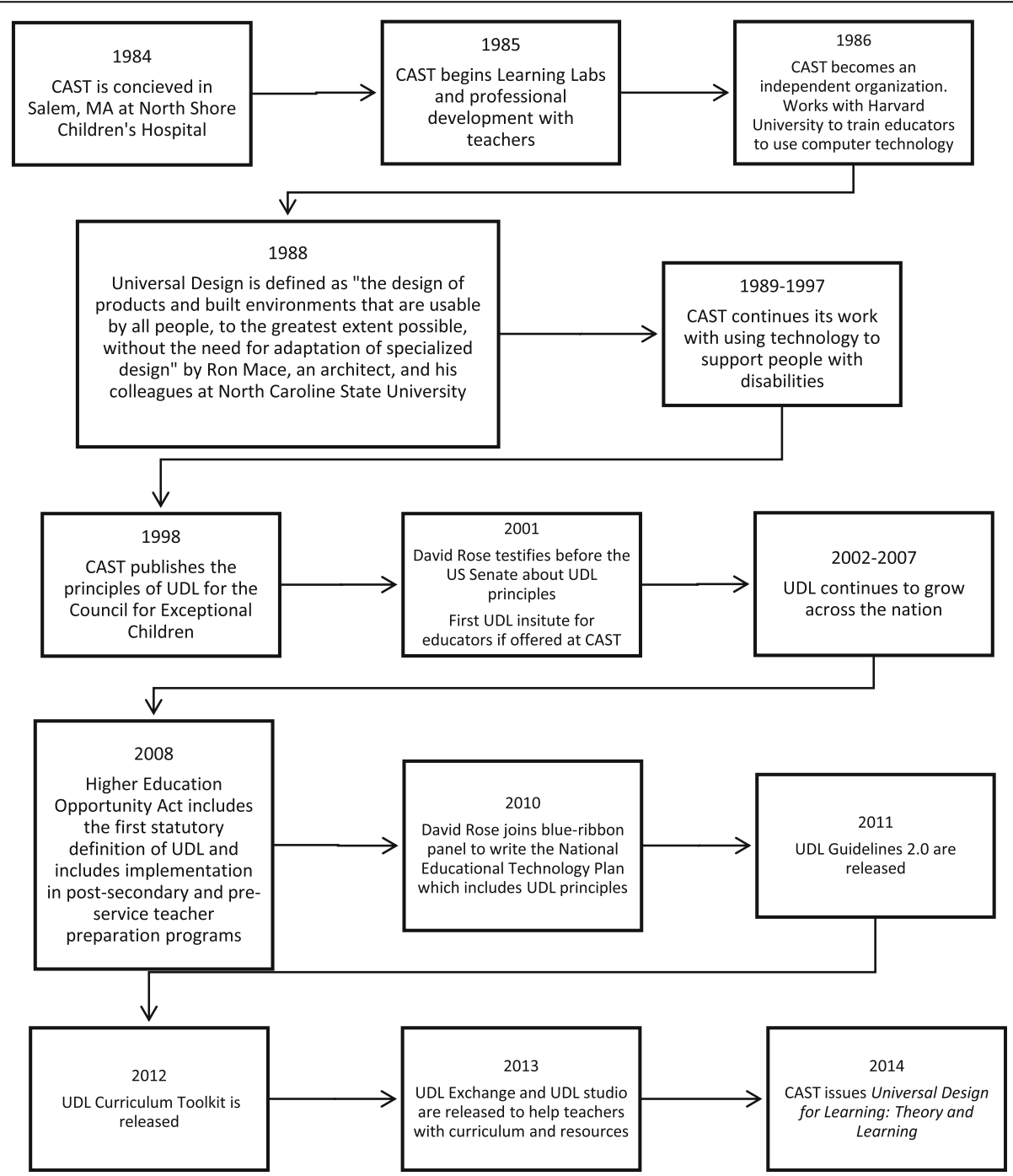

Fig. 1 Timeline of CAST and UDL 
others. Table 1 provides the seven principles Mace's group developed to guide Universal Design in architecture in addition to the principles designed for learning and instruction.

\section{History of CAST and Universal Design for Learning}

In 1984, Anne Meyer, David Rose, Grace Meo, Skip Stahl, and Linda Mensing from the North Shore Children's Hospital in Massachusetts created the Center for Applied Special Technology (CAST) with the goal of using technology to enhance learning for students with disabilities in grades K-12 (Center for Applied Special Technology 2011). CAST has become a leading authority on adopting the principles of UD for education, through Universal Design for Learning (UDL). Instead of focusing on accommodations for students with disabilities, UDL provides a framework to change the actual learning environment (Fovet et al., 2014). CAST's seminal paper introduced the three principles of UDL: using multiple means of representation, expression and action, and engagement (Basham \& Marino 2013). Representation provides varying methods for learners to perceive information. Expression and action provides students options for planning and performing content-specific tasks. Engagement provides opportunities for students to stay involved and motivated in their learning (Center for Applied Special Technology, n.d.). The 3 principles are further described by 9 guidelines and 31 specific checkpoints.

In 2008, the Higher Education Opportunity Act provided the first statutory definition of UDL as "a scientifically valid framework for guiding educational practice that- (A) provides flexibility in the ways information is presented, in the ways students respond or demonstrate knowledge and skills, and in the ways students are engaged; and (B) reduces barriers in instruction, provides appropriate accommodations, supports, and challenges, and maintains high achievement expectations for all students, including students with disabilities and students who are limited English efficient" (U.S. Department of Education, 2008, p. 103). Additionally, the Higher Education Opportunity Act included guidelines for implementation in postsecondary settings and preservice teacher programs. CAST continues to build on the concept that UDL should focus on changing content and curriculum, not students. To this ends, CAST (2011) has developed a number of resources, such as the "UDL on Campus" website, providing postsecondary educators resources for making the classroom accessible to all students; the UDL curriculum toolkit, a web-based platform for developing web-based curricula and content based on UDL (http:// udl-toolkit.cast.org/home); Universal Design for Learning: Theory and Learning, a multimedia book summarizing a decade of research and practice (Meyer et al. 2014); and a variety of free learning tools aimed at educators, parents, and students (http://www.cast.org/our-work/learning-tools.html\#.WNv7yVXyuUk) (Center for Applied Special Technology, 2011).

\section{Universal Design in Postsecondary Education}

The majority of research relating to UDL has been conducted in the $\mathrm{K}-12$ education setting (Rao et al., 2014). In 2001, researchers at the University of Connecticut expanded on the Universal Design for Learning (UDL) and created the nine principles of the Universal Design for Instruction (UDI) to aid faculty in the postsecondary setting in increasing access to curriculum for diverse learners (Rao et al., 2014). As shown in Table 1, UDI retains the seven principles from UD in architecture and adds two principles specific to the educational setting. Universal Instructional Design (UID) is a third commonly used framework for applying UD in postsecondary education, derived from Chickering and Gamson's principles of food practice for undergraduate education (Chickering \& Gamson, 1987; Higbee \& Goff, 2008).

All students learn in many different ways, whether they have a disability or not. Postsecondary courses designed with UDL and include technology applications provide all students with multiple ways to access the curriculum (Izzo and Bauer, 2015). Students without disabilities also benefit from a UDL classroom the same way students with disabilities benefit. They are able to be more engaged and motivated and have a greater interest in their own education (Ralabate, 2011). UDL has provided a framework that challenges the idea of a

Table 1 Universal Design models and their principles

\begin{tabular}{llll}
\hline Model & Universal Design (architecture) & Universal Design for Learning & Universal Design for Instruction \\
\hline Principles & 1. Equitable use & 1. Provide multiple means of representation & 1. Equitable use \\
& 2. Flexibility in use & 2. Provide multiple means of action and expression & 2. Flexibility in use \\
3. Simple and intuitive & 3. Provide multiple means of engagement & 3. Simple and intuitive \\
4. Perceptible information & (Meyer et al., 2014) & 4. Perceptible information \\
5. Tolerance for error & & 5. Tolerance for error \\
6. Low physical effort & 6. Low physical effort \\
7. Size and space for approach and use & 7. Size and space for approach and use \\
(Burgstahler, 2009) & 8. A community of learners \\
& & 9. Instructional climate \\
\end{tabular}


"one-size-fits-all" way of learning. Diversity in classrooms is more than students with disabilities versus students without disabilities. UDL continues to make learning accessible to all students (Edyburn, 2005).

Universal Design is still in its early stages of development in the educational setting (Basham \& Marino, 2013; Rose et al., 2006). Rose et al. (2006) recognizes the distance between research and application of UDL in secondary settings and theory. Presence of UDL in graduate education is rare (Rose et al., 2006).

\section{Results of prior literature reviews}

Roberts et al. conducted a 2011 literature review on UDL in postsecondary education, using the following criteria for their search: (a) empirical studies in peer-reviewed journals; (b) published 2000 or later; and (c) use of UDL, UDI, UID, and UD in postsecondary, college, university, and higher education. Their review identified just eight studies, as shown in Table 2, indicating a lack of research in the effectiveness of UDL in postsecondary settings (Roberts et al., 2011). Most articles focused on student and faculty perspectives of UDL or training preservice teachers and faculty members to implement UDL. Roberts et al. (2011) found the research lacked studies using quantitative methods and studies exploring technology aligned with UDL. Based on these findings, Roberts et al. recommend that future research "operationalize the principles of UDI and investigate its impact on the outcomes of postsecondary education students with and without disabilities" (p. 5).

Rao et al. (2014) conducted a broader review in 2014, focusing on both Pre-K-12 and postsecondary UD educational models (Rao et al., 2014). They used the following inclusion criteria (a) empirical studies; (b) conducted in Pre-K-12 or postsecondary education; (c) referenced UDL, UDI and/or universal instructional design (UID); and (d) published in peer-reviewed journals. Rao et al. (2014) identified 13 studies, of which five were at the postsecondary level and only two used quantitative methods. Results of the two employing quantitative methods indicated an increase in student performance when UDL principles were implemented. In the first study, Schelly, Davies, and Spooner (2011) indicated an increased willingness of instructors to implement UDL in their lessons and an improvement in students' perceptions about how the instructors enacted the principles of UDL (presented information, engaged students, allowed student to express comprehension) after instructor training. The second study by Spooner, Baker, Harris, Ahlgrim-Delzell, and Browder (2007) indicated an increase in preservice teachers' ability to design lesson plans aligned with UDL after a 1-h training, compared to a control group.

Seok et al. (2018) conducted a study to review UDL principles in postsecondary education for students with and without disabilities. They reviewed 17 empirical studies, using the following parameters: (a) participant information, (b) courses and delivery mode, (c) independent and dependent variables, (e) implementation strategies, and (f) effectiveness of implementation. The results of the literature review showed 15 studies with effective strategies using UDL in the postsecondary setting. Each study used some aspect of the Universal Design framework. The findings of this literature review reinforce the need to provide multiple means of representation, expression, and engagement in all coursework. Students with and without disabilities benefit from the use of the UDL framework.

While researchers have conducted reviews on literature on Universal Design (Rao et al., 2014; Roberts et al., 2011; Seok et al., 2018), the literature reviews do not provide a systematic review of UDL in STEM fields. Rao et al. (2014), Roberts et al. (2011), and Seok et al. (2018) conducted systematic literature reviews to articulate current status and future direction for UDL from Pre-K-12 to postsecondary institutions regardless of academic subjects or disciplines. This literature review will fill the gap in relation to UDL in postsecondary STEM programs.

\section{Prior literature reviews}

Prior literature reviews are listed in Table 2.

\section{Purpose of the study}

This literature review seeks to synthesize the existing literature on UD in postsecondary education, specifically for STEM majors. We addressed one question in our literature review: What quantitative and/or mixed methods, empirical research has been done on using the UDL framework in postsecondary STEM majors for students with disabilities?

Table 2 List of literature reviews on UDL

\begin{tabular}{lll}
\hline Author & Number of articles reviewed & Types of articles reviewed \\
\hline Roberts et al. (2011) & 8 & $\begin{array}{l}\text { Pre-K-12 articles referencing universal design educational models } \\
\text { Postsecondary articles referencing universal design educational models }\end{array}$ \\
Rao et al. (2014) & 13 & Postsecondary, college, university, or higher education articles on UDL/UDI/UID/UD \\
Seok et al. (2018) & 17 & Focus on application of UDL principles for postsecondary students with and without disabilities \\
\hline
\end{tabular}




\section{Method}

We searched five databases, cataloging empirical liteature on education, psychology, and science: EBSCOhost to search ERIC, ProQuest, Science Direct, Web of Science, and Sage Publication. The following keywords were used: STEM, UDI/UDL/UD, and postsecondary/college/university/higher education; articles published before 2006 were excluded in order to include only recent research. We used Boolean search terms (AND, OR) in order to limit our searches. We narrowed the identified article set (initially 1202 articles) to UDI/UDL in postsecondary STEM education of students with disabilities. We focused on empirical literature, defined as studies employing an experimental or quasi-experimental design, and mixed methods research to identify the impact of UDL on postsecondary STEM education; thus, we excluded editorials, rejoinders, qualitative analysis, and meta-analysis. As shown in Fig. 2, our final analysis yielded just four studies using quantitative and/or mixed methods to explore the impact of UDL on post-secondary education.

\section{Review of research}

UDI/UDL in education

The list of UDL articles is shown in Table 3.

\section{Results}

Spooner et al. (2007) explored the effects of professional development on including UDL principles into lesson planning and how it affected student's performance in class. Seventy-two graduate and undergraduate students participated in the study at a southeastern university. The participants in the study were enrolled in the following courses: (a) General Curriculum Access, (b) Instructional Planning of Lesson Plans, (c) Middle-Grade Science Methods, and (d) Middle-Grade Math Methods.

Students were randomly placed in either the control or the experiment group by pulling names from a hat. The intervention consisted of a 1-h lecture on UDL and how to incorporate the principles into a lesson plan to include all students in the lesson (the control group received the UDL lesson after the posttest). Students then had to construct their own lesson plans based on a case study provided to them with a student with a severe cognitive disability. The control group had business as usual. The posttest consisted of a new case study in which both groups had to construct a lesson plan utilizing the principles of UDL. A 6-point scoring rubric was used to grade the lessons. A 3-factor ANOVA with repeated measures was completed for each of the dependent variables. Statistically significant effects were found for the total pretest and posttest. The treatment

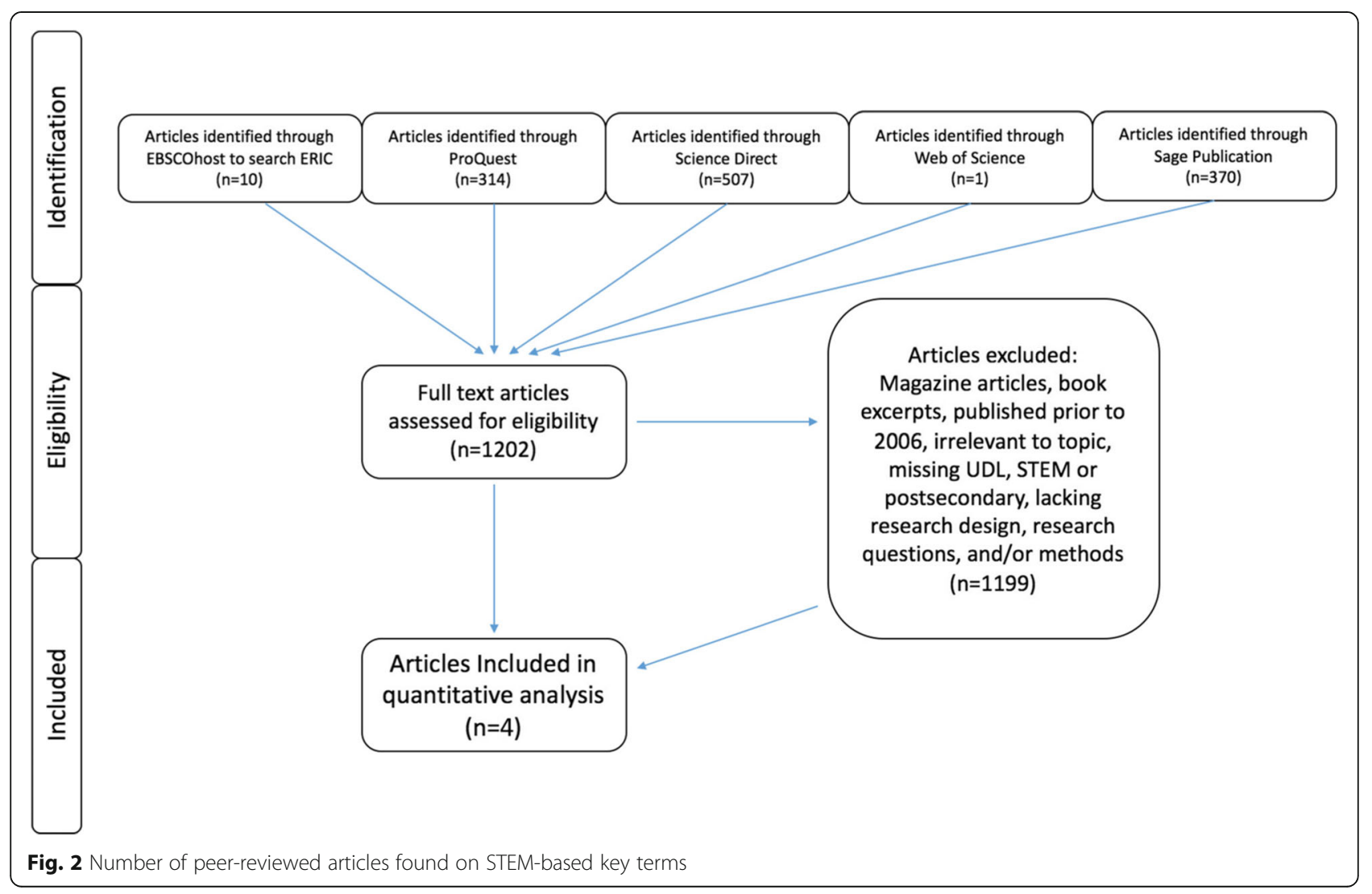


Table 3 List of UDL articles

\begin{tabular}{|c|c|c|c|c|}
\hline $\begin{array}{l}\text { Author } \\
\text { (Year) }\end{array}$ & Methodology & $n$ size & Summary of findings & $\begin{array}{l}\text { What Works } \\
\text { Clearinghouse } \\
\text { Outcomes }\end{array}$ \\
\hline $\begin{array}{l}\text { Spooner, } \\
\text { Baker, } \\
\text { Harris, } \\
\text { Ahlgrim- } \\
\text { Delzell, } \\
\text { Browder } \\
\text { (2007) }\end{array}$ & $\begin{array}{l}\text { Quantitative } 3 \text { factor ANOVA } \\
{ }^{*} \text { Comparing class } \\
{ }^{*} \text { Treatment group } \\
\text { *Pre- and posttest score }\end{array}$ & $\begin{array}{l}72 \text { graduate and } \\
\text { undergraduate students }\end{array}$ & $\begin{array}{l}\text { Statistically significant results within the } \\
\text { pre- and posttest }\end{array}$ & $\begin{array}{l}\text { Meets WWC } \\
\text { group design } \\
\text { standards without } \\
\text { reservations }\end{array}$ \\
\hline $\begin{array}{l}\text { Street et } \\
\text { al. (2012) }\end{array}$ & $\begin{array}{l}\text { Quantitative and qualitative } \\
{ }^{*} \text { Course GPA } \\
{ }^{*} \text { Cumulative GPA } \\
\text { *STEM persistence data } \\
\text { (registering for STEM } \\
\text { classes in the next } \\
\text { semester) } \\
\text { *Pre- and postintervention } \\
\text { scores - Learning and } \\
\text { Study Strategies Inventory } \\
\text { (LASSI) } \\
{ }^{*} \text { Course evaluation } \\
\text { *Focus group intervention } \\
\text { was Peer-Led Team } \\
\text { Learning }\end{array}$ & $\begin{array}{l}16 \text { college freshmen or } \\
\text { sophomores with LD or } \\
\text { ADHD }\end{array}$ & $\begin{array}{l}\text { Course and cumulative GPA showed } \\
\text { no statistically significant difference } \\
\text { between treatment group and control } \\
\text { group. } \\
\text { LASSI scores showed significant increases } \\
\text { in the areas of skill, will, and } \\
\text { self-regulation. } \\
14 \text { students persisted ( } 2 \text { found ineligible } \\
\text { academically) } \\
\text { In the focus groups, students found } \\
\text { peer-led team learning to be helpful. }\end{array}$ & $\begin{array}{l}\text { Meets WWC } \\
\text { group design } \\
\text { standards with } \\
\text { reservations }\end{array}$ \\
\hline $\begin{array}{l}\text { Moon et } \\
\text { al. (2011) }\end{array}$ & $\begin{array}{l}\text { Mixed-methods } \\
\text { *McConney, Rudd, and } \\
\text { Ayres' results synthesis } \\
\text { method } \\
\text { *Campbell's pattern matching method } \\
\text { *Workshop survey } \\
\text { *Focus group protocols } \\
\text { *Classroom observations }\end{array}$ & 15 faculty members & $\begin{array}{l}\text { Faculty claim the intervention led them } \\
\text { to use more inclusive teaching methods. }\end{array}$ & $\begin{array}{l}\text { Meets WWC } \\
\text { group design } \\
\text { standards with } \\
\text { reservations }\end{array}$ \\
\hline $\begin{array}{l}\text { Kreider et } \\
\text { al. (2018) }\end{array}$ & $\begin{array}{l}\text { Mixed-methods qualitative data } \\
\text { *Meeting notes } \\
\text { *Written feedback sheets } \\
\text { *Audio recordings } \\
\text { *Group meetings } \\
\text { Quantitative data } \\
\text { *Academic Behavioral Confidence } \\
\text { Scale (ABCS) } \\
\text { *Institutional Integration Scale (IIS) } \\
\text { *Personal Growth Initiative Scale } \\
\text { (PGIS) } \\
\text { Survey questions }\end{array}$ & $\begin{array}{l}52 \text { undergraduate STEM } \\
\text { students with learning } \\
\text { disabilities registered with the } \\
\text { campus disability office }\end{array}$ & $\begin{array}{l}\text { Statistically significant improvements in } \\
\text { self-reported ratings in STEM professional } \\
\text { development and self-advocacy } \\
\text { Statistically significant increase in the ABCS } \\
\text { scores pre to post. } \\
\text { Significant increase in IIS scores. } \\
\text { No significant change in PGIS. }\end{array}$ & $\begin{array}{l}\text { Meets WWC } \\
\text { group design } \\
\text { standards without } \\
\text { reservations }\end{array}$ \\
\hline
\end{tabular}

GED general education students, HID high incidence disability, UDL Universal Design for Learning

group saw increased means in both general and special educators between their pretest and posttest. The control group did not find an increase in the mean scores from pretest to posttest.

The authors provided an hours' worth of instruction in UDL planning improves lesson-planning skills. Teachers who thought they were restricted by time and a lack of instruction made improvements in their planning skills to include UDL components which would include students with disabilities in their lessons.

Street et al. (2012) investigated the effect of training small group leaders in Universal Design on the utility of Peer-Led Team Learning (PLTL) for students with learning disabilities and/or ADHD taking introductory chemistry and calculus courses. PLTL is a popular academic support model in higher education where junior- and senior-level students who excelled in courses lead small group study sessions focused on strengthening students' collaboration and problem-solving skills. Prior data indicated that SWD did not get the similar boosts in their academic achievement from PLTL as their peers without disabilities. Street et al. (2012) trained experienced PLTL leaders in UDI and investigated the impact of the revised model, Mastery PLTL (MPLTL), on small groups of exclusively SWD. The researchers used both quantitative and qualitative measures, including variables such as course GPA, cumulative GPA, STEM persistence data (registering for STEM classes in the next semester), preand postintervention scores on the Learning and Study Strategies Inventory (LASSI), and a course evaluation. The 
study did not include initial GPA scores, and as a result, the researchers could not make a comparison on student growth. Sixteen students participated in the study across two semesters.

Peer mentors attended a 1-day orientation workshop and weekly 1-h seminar on UDI and participated in weekly hour-long sessions focused on training them to present information in ways more accessible to students with information-processing and/or attentional needs. Additionally, they attended 1 -h weekly preparation sessions with the PLTL mentors to review the week's problems. MPLTL leaders created written and video-based "templates" based on a UDI principle, which were defined as "any tool or strategy that enhances students' understanding, retention, or application of course concepts, formulas or procedures" (Street et al., 2012, p. 367).

The intervention did not result in a statistically significant difference between the comparison groups based on average course and cumulative GPA. In the first semester, SWD who participated in the MPLTL sessions had the lower course GPAs compared both to SWD who did not participate in MPLTL and all students. In the second semester, MPLTL students outperformed nonparticipating SWD in chemistry, but not calculus, where all SWD outperformed the general population. Two students were disqualified to continue in their STEM major after the study due to academic ineligibility. However, the other 14 students had a higher rate of persistence (715) compared to non-participating SWD (61\%). The LASSI showed significant improvement in all three focus areas, including skill, will, and self-regulation. MPLTL students found the intervention to be helpful in providing strategies to study and perform better on assignments.

Moon et al. (2011) published recommendations for evaluating programmatic interventions aimed at improving postsecondary STEM education for SWD and included preliminary findings from SciTrain University. SciTrain University combines in-person workshops to inform faculty about disabilities and working with SWD, with a focus on using accessible pedagogy in large lecture classes, laboratories and online learning environments, and online courses to support use of project resources at external institutions. The evaluation employed mixedmethods, including demographic and performance data for students enrolled in SciTrain courses and classroom observations and faculty online journal reflections to determine the efficacy of training given to faculty members from two different universities (Moon et al., 2011). Fifteen faculty members from Georgia Tech and University of Georgia participated in the study, though it was noted retention of members was difficult. Student GPAs were tracked for 2 years. While preliminary analysis of students' course-by-course grades did not indicate an improvement in student performance, SWD reached their goals of course completion and passing grades. Classroom observations indicated an increase in accessibility for SWD, including improvements in class note takers, oral communication, visual aids, and electronic learning support. Journal reflections showed an increase in the application of UDL strategies in trying to make better class materials and using different teaching methods to engage all students in the lessons (Moon et al., 2011).

Kreider et al. (2018) researched the benefits of the Comprehensive Support for STEM Students with Learning Disabilities ( $\left.\mathrm{CS}^{3} \mathrm{LD}\right)$, a campus-based framework for supporting students with disabilities. The $\mathrm{CS}^{3} \mathrm{LD}$ model supports students with learning disabilities (LD) at three different levels, institutional, personal, and interpersonal. At the institutional level, experts in LD were employed while the personal and interpersonal supports were simultaneously offered. Support for academics included career support and mentorship. The model also focused on the student's health and well-being.

Kreider et al. (2018) utilized a mixed-methods design for their 4-year project. Qualitative data consisted of focus group discussions, participant communications, and individual interviews. Quantitative data came from survey and implementation data, including the Academic Behavioral Confidence Scale (ABCS), the Institutional Integration Scale (IIS), the Personal Growth Initiative Scale (PGIS), and survey questions. The researchers used a one group pre/posttest approach. The goal of the project was to analyze "model implementation, implementation outcomes, and potential for institutional adoption of model activities" (p. 3). The study was conducted at the University of Florida and included 52 undergraduate STEM students with LD. Mentors consisted of 34 faculty members and 57 graduate students and were also instructed in and implemented the principles of UDL in their sessions. Study experts in LD held monthly group discussion meetings with the undergraduate participants. Undergraduate participants also met individually with their graduate student mentor at least bi-weekly.

Results of the study showed an increase in the self-efficacy of the undergraduate participants. Scores from the ABCS and the IIS showed a statistically significant increase compared to baseline scores. Scores from the PGIS did not significantly change. Overall results of the study showed a positive change in success for STEM students with LD.

\section{Conclusions}

As more students with disabilities endeavor to enter STEM fields, STEM faculty need to be prepared to engage all students in their lessons (Newman et al., 2011). Universal Design for Learning is one way to make 
every lesson accessible to every student. By making STEM content accessible to all students, colleges and universities may see an increase in STEM enrollment by underrepresented populations (Newman et al., 2011).

Using UDL in postsecondary education is one way to decrease the barriers students with disabilities face in STEM education. Creating classrooms that are accessible to all students opens pathways for students with disabilities they may not have considered before. Universal design has been researched at the secondary level and shows marked improvement for students with disabilities (Rao et al., 2014). Continuing the research that is done at the secondary level can help students with disabilities transition more smoothly into postsecondary STEM majors. Projects that focus on helping professors and instructors create syllabi, lessons, and assessments that are accessible will lead the way for students of all abilities to be successful in STEM fields. As more students with disabilities enroll in STEM courses, instruction needs to be tailored to fit the needs of all students. Planning ahead for all abilities, which the UDL framework advocates, will help relieve stress from professors trying to adapt at the last minute for unique student abilities. Knowing lessons are already planned and take into account learner variability will also provide a level of comfort for students knowing they will be supported throughout their coursework.

The number of empirical research studies exploring the efficacy of UD for postsecondary STEM education remains too small to indicate widespread success of the model and to provide examples for interested instructors. While a few empirical research articles were found in this review, many faculty are already implementing the principles of UDL (Basham \& Marino, 2013). Most research on UDL in postsecondary education has been in non-STEM majors. Many studies qualitatively examined the perspectives of students and faculty on the use of UDL in postsecondary education. However, there is limited evidence on the results of using UDL in a postsecondary setting, specifically targeting student growth. Since executive function (EF) skills are common across several diagnoses, including attention deficit hyperactivity disorder, learning disabilities, and autism spectrum disorder, we suggest EF disorders are an important focus for future research (Barkley, 2012; Denckla, 2007; Pellicano, 2012).

Additionally, researchers should be specific about the types of instruction they are investigating. Recent calls in postsecondary STEM education emphasize the need for "active learning," which often includes group work and increased need for self-regulation both during and outside of formal class time. While these strategies have shown benefit for students overall (Freeman et al., 2014), the research base does not exist to determine their effectiveness for SWD. This research is necessary because active learning could provide both advantages and disadvantages for students with EF disorders. For example, while a variety of instructional practices, such as mini-lectures, think-pair-share, demonstrations, and student-led presentations, may provide multiple means to access information (aligned with UDL), the many small, timed assignments that result may tax executive function and be difficult for students to track. Group and teamwork may allow SWD to capitalize on strengths and minimize impact of weaknesses, but groups or teams may not be well composed, may draw attention to students' weaknesses, and may tax social skills. In redesigned learning spaces, the instructor's presence throughout entire classroom and use of student work may help hold attention; however, there may be no "front" of the classroom, leading to difficulties with attention.

Given the lack of research found for UDL in postsecondary STEM, additional research is necessary to validate the effectiveness of the UDL principle in this setting. The National Science Foundation, the U.S. Department of Education, and the National Institute of Health have funding opportunities for research in postsecondary STEM education for underrepresented populations.

\section{Limitations}

Several limitations may affect the results of this review. Relevant articles may not have been indexed by databases searched or may have used different key terms. Our search focused on "STEM," and articles may emphasize a specific discipline within STEM (such as physics). Additionally, some articles used the ideals of UDL but did not classify their approach as UD and were not included. Articles not published in peer-reviewed journals were not included in this search. In a search on the National Science Foundation's website, two ongoing projects were found to increase the number of students with disabilities in STEM majors. The components used in each project were based on the three UDL principles, however either the project did not use the term UDL or it did not have research based articles that met the three criteria used in this review: STEM, postsecondary, and UDL.

\footnotetext{
Abbreviations

ABCS: Academic Behavioral Confidence Scale; ADHD: Attention deficit hyperactivity disorder; ANOVA: Analysis of variance; CAST: Center for Applied Special Technology; CS ${ }^{3}$ LD: Comprehensive Support for STEM Students with Learning Disabilities; EF: Executive function; GPA: Grade point average; IIS: Institutional Integration Scale; LASSI: Learning and Study Strategies Inventory; LD: Learning disabilities; MPLTL: Mastery Peer-Led Team Learning; NLTS2: National Longitudinal Transition Study-2; PGIS: Personal Growth Initiative Scale; PLTL: Peer-Led Team Learning; STEM: Science, technology, engineering, mathematics; SWD: Students with disabilities; SWoD: Students without disabilities; UD: Universal Design; UDI: Universal Design for
} 
Instruction; UDL: Universal Design for Learning; WWC: What Works Clearinghouse

\section{Acknowledgements}

Not applicable.

\section{Funding}

The material in this manuscript is based upon work supported, in part, by the National Science Foundation under Grant Award Number 1612009. Any opinions, findings, and conclusions or recommendations in this material are those of the author(s) and do not necessarily reflect the views of the National Science Foundation.

\section{Availability of data and materials}

Not applicable.

\section{Authors' contributions}

JS made substantial contributions to the conception, design, analysis, and interpretation of data. EV, JC, and WJ were involved in revising the article for important intellectual content. All authors read and approved the final manuscript.

\section{Ethics approval and consent to participate}

Not applicable.

\section{Competing interests}

The authors declare that they have no competing interests.

\section{Publisher's Note}

Springer Nature remains neutral with regard to jurisdictional claims in published maps and institutional affiliations.

\section{Author details}

${ }^{1}$ Department of Child, Family, and Community Science, University of Centra Florida, Orlando, FL 32816, USA. Physics Department, University of Central Florida, Orlando, USA.

Received: 13 September 2018 Accepted: 10 February 2019

Published online: 04 March 2019

\section{References}

ACCESS Project. (2011). Universal design for learning: a concise introduction. U.S Department of Education. Retrieved from http://accessproject.colostate.edu/ $\mathrm{udl} /$ modules/udl introduction/udl concise intro.pdf.

Barkley, R. A. (2012). Executive functions: what they are, how they work, and why they evolved. New York: Guilford Press.

Basham, J. D., \& Marino, M. T. (2013). Understanding STEM education and supporting students through universal design for learning. Teaching Exceptional Children, 45(4), 8-15.

Burgstahler, S. (2009). Universal Design of Instruction (UDI): definition, principles, guidelines, and examples. Disabilities, Opportunities, Internetworking, and Technology (DO-IT). Retrieved from https://files.eric.ed.gov/fulltext/ ED506547.pdf

Center for Applied Special Technology. (2011). CAST timeline. Retrieved November 2, 2016, from http://www.cast.org/about/timeline.htm

Center for Applied Special Technology. (n.d.). UDL on campus: home. Retrieved January 23, 2017, from http://udloncampus.cast.org/home\#.WIYVqLYrKRs

Chickering, A. W., \& Gamson, Z. F. (1987). Seven principles for good practice in undergraduate education. AAHE Bulletin, 3, 7.

College of Design, N. S. U. (2008). About the center - Ronald L. Mace. Retrieved November 2, 2016, from https://www.ncsu.edu/ncsu/design/cud/about_us/ usronmace.htm

Denckla, M. B. (2007). Executive function: building together the definitions of attention deficit/hyperactivity disorder and learning disabilities. In L. Meltzer (Ed.), Executive function in education (pp. 5-18). New York: Guilford Press.

Edyburn, D. (2005). Universal design for learning. Special Education Technology Practice, 7, 16-22.

Fovet, F., Mole, H., Jarrett, T., \& Syncox, D. (2014). Like fire to water: building bridging collaborations between disability service providers and course instructors to create user friendly and resource efficient UDL implementation material. Collected Essays on Learning and Teaching, 7(1), 68-75.
Freeman, S., Eddy, S. L., McDonough, M., Smith, M. K., Okoroafor, N., Jordt, H., \& Wenderoth, M. P. (2014). Active learning increases student performance in science, engineering, and mathematics. Proceedings of the National Academy of Sciences, $111(23), 8410-8415$ https://doi.org/10.1073/pnas. 1319030111

Higbee, J. L., \& Goff, E. (2008). Pedagogy and student services for institutional transformation: implementing universal design in higher education. Center for Research on Developmental Education and Urban Literacy. Retrieved from http://eric.ed.gov/?id=ED503835

Izzo, M. V., \& Bauer, W. M. (2015). Universal design for learning: enhancing achievement and employment of STEM students with disabilities. Universal Access in the Information Society, 14(1), 17-27 https://doi.org/10.1007/s10209-013-0332-1.

Kreider, C. M., Medina, S., Lan, M.-F., Wu, C.-Y., Percival, S. S., Byrd, C. E., et al. (2018). Beyond academics: a model for simultaneously advancing campusbased supports for learning sisabilities, STEM students' skills for selfregulation, and mentors' knowledge for co-regulating and guiding. Frontiers in Psychology, 9, 1466 https://doi.org/10.3389/fpsyg.2018.01466.

Lee, A. (2011). A comparison of postsecondary science, technology, engineering, and mathematics (STEM) enrollment for students with and without disabilities. Career Development for Exceptional Individuals, 34(2), 72-82 https://doi.org/10.1177/0885728810386591.

Lee, A. (2014). Students with disabilities choosing science technology engineering and math (STEM) majors in postsecondary institutions. Journal of Postsecondary Education and Disability, 27(3), 261-272.

Meyer, A., Rose, D. H., \& Gordon, D. (2014). Universal design for learning: theory and practice. Wakefield, MA: CAST Professional Publishing.

Moon, N. W., Utschig, T. T., Todd, R. L., \& Bozzorg, A. (2011). Evaluation of programmatic interventions to improve postsecondary STEM education for students with disabilities: Findings from SciTrain University. Journal of Postsecondary Education and Disability, 24(4), 331-349.

Newman, L., Wagner, M., Knokey, A.-M., Marder, C., Nagle, K., Shaver, D., \& Wei, X. (2011). The post-high school outcomes of young adults with disabilities up to 8 years after high school: a report from the national longitudinal transition study-2 (NLTS2). National Center for Special Education Research. Retrieved from http://eric.ed.gov/?id=ED524044.

Olson, S., \& Riordan, D. G. (2012). Engage to excel: producing one million additional college graduates with degrees in science, technology, engineering, and mathematics. Report to the president. Executive Office of the President. Retrieved from http://eric.ed.gov/?id=ED541511

Pellicano, E. (2012). The development of executive function in autism. Autism Research and Treatment, 2012, 146132 https://doi.org/10.1155/2012/ 146132.

Ralabate, P. K. (2011). Universal Design for Learning: meeting the needs of all students. Retrieved January 23, 2017, from http://www.readingrockets.org/ article/universal-design-learning-meeting-needs-all-students

Rao, K., Ok, M. W., \& Bryant, B. R. (2014). A review of research on universal design educational models. Remedial and special education, 0741932513518980 https://doi.org/10.1177/0741932513518980

Roberts, K. D. (2010). Topic areas to consider when planning transition from high school to postsecondary education for students with autism spectrum disorders. Focus on Autism and Other Developmental Disabilities, 25(3), 158162 https://doi.org/10.1177/1088357610371476

Roberts, K. D., Park, H. J., Brown, S., \& Cook, B. (2011). Universal design for instruction in postsecondary education: a systematic review of empirically based articles. Journal of Postsecondary Education and Disability, 24(1), 5-15.

Rose, D. H., Harbour, W. S., Johnston, C. S., Daley, S. G., \& Abarbanell, L. (2006). Universal design for learning in postsecondary education: reflections on principles and their application. Journal of Postsecondary Education and Disability, 19(2), 135-151.

Schelly, C. L., Davies, P. L., \& Spooner, C. L. (2011). Student perceptions of faculty implementation of universal design for learning. Journal of Postsecondary Education and Disability, 24(1), 17-30.

Seok, S., DaCosta, B., \& Hodges, R. (2018). A systematic review of empirically based Universal Design for Learning: implementation and effectiveness of Universal Design in education for students with and without disabilities at the postsecondary level. Open Journal of Social Sciences, 06(05), 171-189 https://doi.org/10.4236/jss.2018.65014.

Spooner, F., Baker, J. N., Harris, A. A., Ahlgrim-Delzell, L., \& Browder, D. M. (2007) Effects of training in universal design for learning on lesson plan development. Remedial and Special Education, 28(2), 108-116. https://doi.org/ $10.1177 / 07419325070280020101$ 
SRI International. (2002). NLTS data brief: introducing the NLTS2. a report from the National Longitudinal Transition Study-2. Retrieved from http://www. ncset.org/publications/viewdesc.asp?id=248

Stamp, L., Banerjee, M., \& Brown, F. C. (2014). Self-advocacy and perceptions of college readiness among students with ADHD. Journal of Postsecondary Education and Disability, 27(2), 139-160.

Street, C. D., Koff, R., Fields, H., Kuehne, L., Handlin, L., Getty, M., \& Parker, D. R. (2012). Expanding access to STEM for at-risk learners: a new application of universal design for instruction. Journal of Postsecondary Education and Disability, 25(4), 363-375.

U.S. Department of Education. (2008). Higher education opportunity act-2008. U. S. Department of Education. Retrieved from https:/www2.ed.gov/policy/ highered/leg/hea08/index.html\#dcl

U.S. Department of Housing and Urban Development. (1988). Universal design: housing for the lifespan of all people. Washington, DC: U.S. Dept. of housing and urban development, Office of Public Affairs: Office of Intergovernmental Relations, [1988].

\section{Submit your manuscript to a SpringerOpen ${ }^{\circ}$ journal and benefit from:}

- Convenient online submission

- Rigorous peer review

- Open access: articles freely available online

High visibility within the field

- Retaining the copyright to your article

Submit your next manuscript at $\boldsymbol{\wedge}$ springeropen.com 